\title{
The Nigerian Experience: Management of The Civil Service
}

\author{
${ }^{1}$ Abel Owotemu, ${ }^{2}$ Dr. Cross Ogohi Daniel \\ ${ }^{1}$ Department of Business Administration, Faculty of Management Sciences, Nile University of Nigeria, \\ abelowotemu@hotmail.com \\ ${ }^{2}$ Department of Business Administration, Faculty of Management Sciences, Nile University of Nigeria, Abuja, \\ Nigeria \\ danielcross@,nileuniversity.edu.ng
}

\begin{abstract}
The research paper considered the civil service as the engine room for the administration of human and non-human resources of the country, state, or local government in the business of governance. The Nigeria civil service has a history behind it, and it has evolved over the years playing significant roles in the growth of the country's policy development and administration, particularly since independence. While, the activities of the civil service may have come short in some instances, the structure has also had tremendous accolades at some other times in the implementation of the various government initiatives at different times. Although, the issue of the socio-political menace of "corruption" is a concept that has hung around the Nigerian civil service like a plaque. A number of the civil service reforms carried out most especially in the early 1970s to early 1980s were predominantly on accountability, efficiency, and productivity of the civil service which could all be traced to the issue of corruption within the civil service structure as at that period. The research paper has therefore conducted a thorough theoretical review of the management of the Nigerian civil service with the objective of proffering some solutions to the various deficiencies of the system as it is today.
\end{abstract}

Key words: Civil service, MDGs, Corruption, Indirect rule, Reforms.

DOI: $10.7176 / \mathrm{EJBM} / 13-2-06$

Publication date: January $31^{\text {st }} 2021$

\section{Introduction}

The actualization of robust governance in any nation is promptly propelled effectively and efficiently via the availability of adequate services for its citizenry. The efficient dispatchment of such services is chaired by the executive arm of government called "Civil Service" (Adedire, 2014). Civil Service is proclaimed as the administrative bureaucracy of any nation conferred with the implementation and enforcement of government policies and programmes.

The constitutes the brain box of any sovereign nation as it attracts a nations' uniquely adorned talents for formidably established centres of education ranging from universities, research institutes and the array of diversity in the educational system. Thus, competent initiatives are formed and constantly reviewed to enhance eminence and mission of self-governance (Nwakanma, 2014). Adedayo (2013) postulated that the Civil Service is not just an initiative of modern era as it draws back to the era of ancient civilization. With the emanation of sovereign states and the refinement of the parliamentary regime of government, the Civil Service emerged as the keystone of the executive arm of government (Adedire, 2014). It is therefore inevitable that the Millennium Development Goals (MDG's) to be achieved in the $21^{\text {st }}$ century, the duties of the Civil Service must not be trivialized. The aforementioned statement calls to mind the pivotal contributions of Civil Service in endorsing development in East-Asia (Adedire, 2014 as cited in Thomas, 1995). Olaopa (2013) further buttressed the Thomas Taylor Meadow's conclusion on the trounce of China. The regime of the Chinese Empire can be attributed to good governance which constituted the eloquent embodiment of men with talents.

Nigeria's Civil Service roots its existence to an array of constitutional and administrative crux (Adedire, 2014). Nigeria's administrative lore experienced an iconic refinement of the Civil Service structure in 1954 as it composed of grounded Nigerian styled framework. Proceeding this period, the civil service was basely under the colonial rule. The Civil Service recorded tremendous workable reforms that enabled appropriate transformation of the system (Olaopa, 2013). Subsequently, studies revealed that the Civil Service productive competence and performance retrenched partly due to lack of substantial commitment on the part of the Civil Service to government engagements and low service morale channelled to poor remuneration (Adedire, 2014). This is detrimental to the public service dispatchment and as such there is urgent need to boost the confidence level and morale of the working force in order to achieve the stipulated Millennium Development Goals (MDG's). 
The study lays emphasis on Nigeria's Civil Service and highlights viable information on the selected subject matter. The scope of the study is developed within Nigeria as it is one of developing nations pondering on values rather than result or change emplacement.

\section{Literature Review}

2.1 Evolution of Civil Service in Nigeria

The Nigerian Civil Service has evolved over the years dating back to the $19^{\text {th }}$ century when the administrative organization that was set up by the Royal Niger Company was handed over to the British administration, with the specific purpose to sustain and stabilize the capitalist state structure of the colonial rulers. Essentially, the basic function of the civil service administration in the country at the early stage of its evolution was to maintain law and order in support of the colonial agenda of the British administration. The civil service, at that time, was principally dominated by colonial officials as Nigerians were deliberately excluded in the service, especially at the senior cadre. For example, by 1948 only 172 (representing 7\%) of the 2,297 senior civil servants were Nigerians; the proportion hiked to only 19\% at independence (Adedire, 2014).

As a result, British government established different hierarchical positions of Governor, Chief Magistrate, Colonial Secretary and Senior Military Officers, Offices of Private Secretary to the Governor, Auditor for Public Accounts, Chief Clerk, and Collector of Customs. These public bureaucracies was established as the essential ingredient, livewire, and sine-quo-non for the consolidation of pre-colonial state structure in Nigeria.

With indirect rule, caliphate officials were transformed into salaried district heads and became, in effect, agents of the British authorities, responsible for peacekeeping and tax collection in their respective domain without any formal power to initiate development projects to improve socio-economic development (Ogunrotifa, 2014). The balance of power rest squarely with the colonial official (governor-General) who has the power to remove any erring Emir at will.

The evolution of the Nigerian character of the civil service reached its culmination in the post-1954 period with series of reforms that constituted the beginning of the institution of the civil service system in Nigeria. Thus, from 1954, the civil service system generally became the centre of furious and progressive reforms meant to ensure that the evolution of the system would transform it into an adequate institution around which the nascent postindependence state would become true to its stated ideals of providing basic amenities to the Nigerian masses who endured the horrors of colonial administration and its exploitative logic (Adedire, 2014).

However, between 1934 and 2015, the Nigeria civil service has experienced over twenty-four reforms covering the Hunt Commission -1934, the Harragin Commission -1946, the Foot Commission - 1948, Adebo Commission - 1954, the Gorsuch Commission - 1954, and Mbanefo Commission - 1959, the Morgan Commission - 1963, the Elwood Commission - 1966, the Adebo Commission - 1971, the Udoji Commission - 1974, the Dotun Philips Commission - 1988, the Ayida Commission - 1995, the various Obasanjo reforms between 1999-2007, the Yar'Adua reforms 2008-2010, and the Jonathan reforms 2011-2015 (Obioji, 2019)

\subsection{Causes of Inefficiency in Nigeria's Civil Service}

The Nigerian civil has from its always performed poorly in terms of delivery on its mandate. Consequently, a lot of reforms have been carried out in the past as already enumerated with a view to identifying and overcoming the various challenges leading to the poor performance. In spite of these, the civil service in Nigeria still remains largely inefficient and ineffective. This has been attributed to the following challenges.

\section{Poor selection, orientation and training.}

The process of recruiting new staff is usually flawed as there is no strategy in place to select people who are competent or qualified for the position. The process is usually non transparent and marred by a lot of irregularities. Also, those recruited are not properly oriented as to their job requirements and trained to carry out their duties efficiently.

\section{Tribalism, favoritism and Nepotism}

This is usually the reason for non-transparency in the recruitment process. It also affects promotions and postings which are usually not based on merit based often on tribal, religious or other mundane considerations not related to job performance or suitability. This invariably leads to putting square pegs in round holes thus leading to poor performance on the job. 
Bureaucracy

Bureaucracy means adhering strictly to official rules and regulations and also following precedents when implementing government policies and decisions. The aim of bureaucracy is to ensure uniformity and impartiality in civil service functions but it more often than not ends up slowing down the work of government. It leaves little room for the initiative on the part of the civil servants and also breeds corruption due to the resultant bottlenecks.

\section{Bribery and corruption}

This is the demand for monetary inducement or other forms of gratification by civil servants before the discharge of their lawful duties to the public. This is a major handicap to an efficient and effective civil service as it slows down civil service operations by creating unnecessary tolls or barricades. Corruption has generally been attributed to both the poor conditions of service and greed.

\section{Political Interference}

This is a situation where political office holders do not allow the civil servants the necessary freedom to implement government policies effectively by trying to micro manage their activities often for corruption or political patronage. This involves the waiver or breach of due process in contracts awards, recruitment and postings etc thus hampering the smooth operations and efficiency of the civil service.

\section{Over staffing and poor job description}

The civil service work force is usually over bloated as recruitment is not usually based on needs assessment but on political expediency and favoritism. Consequently most do not fit into any job description or the job descriptions are poorly designed or both. This results in the wastage of manpower and financial resources. Such a system cannot yield an efficient outcome as it is unproductive and a big challenge to the civil service.

\section{Ineffective Organization}

The organization structure in the civil service is often defective or not strictly followed due to political interference or irresponsibility on the part of the office holders. The 14 management principles as enunciated by Henri Fayol are usually not fully instituted or implemented leading to distortions in organizational hierarchy, command structure, spirit de corps etc leading to very low motivation and inefficient output.

\subsection{Strategies for Effective Service Delivery of Nigeria Civil Service in $21^{\text {st }}$ Century}

In view of increased demand for the efficient and effective delivery of public sector focused services across the world and Nigeria inclusive, modern strategies for improved service delivery is required. Also, it is important to note that management philosophy and leadership are key elements and requirements with regards to improving the performance of public sector institutions as well as essential tools for achieving development and inspiring confidence in public sector or government. As noted by Ojokuku (2012), in terms of leadership and organizational performance, leadership Style and organizational performance have a positive relationship.

Also, as noted from the works of Comaniciu et al (2012), Rohm, (2002), the measurement of organizational performance or efficiency were on budget utilization, service efficiency levels and process improvement initiatives. Al-Maktoum (2013) had also noted that, Leadership characteristics, such as strategic determination of vision and direction, willingness to challenge old procedures and rules, ability to garner support, and the ability to act as a good role model are all crucial in change management and achieving desired results.

\subsection{Challenges in Determining Public Sector Efficiency or Performance Management}

In view of determining civil service and public sector service delivery and efficiency, Borne et al (2006) also made mention of the challenges in developing public sector service delivery and performance indicators due to issues like handling the concept of performance, methods of obtaining performance data and evaluation of such public-sector performance data.

These challenges are driven by the complexity and multidimensional nature of public-sector performance due to other details like financial records, quality of service, and fulfilment of social and environmental requirements amongst others. This is because all goals are not measurable and as a result the need or use of measures such as bench marking analysis to address these seemingly unmeasurable details.

According to Newcomer (2003) there are challenges that may constitute obstacles towards the implementation of a public-sector performance management system for ensuring efficient service delivery. These challenges may include communication difficulties, lack of prerequisite analytical skills of leaders and stakeholders involved in 
the evaluation process, lack of skills or lack of sophistication with evaluation methods and the impact of political factors.

Stefanescu et al (2010) also identified certain causes of difficulties in defining and measuring public sector service delivery and performance such as the diversity with which performance is perceived, nature of the offered public service, complexity of the socio-economic environment, nature of service users, and the influence of political structures and policies amongst other issues like is the case with Nigeria where factors like Federal character as a requirement for talent selection and appointment of Leaders and Managers in the Public Sector.

The following could be considered as strategies for effective public sector service delivery and performance;

Proposal 1: Scholars like Profiroiu (2001), have noted the challenges with establishing public sector performance because of the complex role being performed by the public sector. It is however noted that an alternative could be to define performance in the light of the interplay between objectives, means and results (hence performance would be the outcome of combining efficiency, effectiveness, and proper budgeting).

Proposal 2: Handler et al (2004) also proposes an alternative to measuring or tracking performance in the public sector through indexes that measure or relay expectations such as business confidence, standard of living and gross domestic production indexes about the public sector measuring and describing activities of public sector institutions.

Proposal 3: Where generally accepted criteria for public sector performance is difficult to come by performance in the public sector could be made more comprehensive through a review of the interplay between inputs, process, outputs and outcomes using strategic intents like; are we doing the things right? And are we doing the right things? As encapsulated in Diagram 2.2 below by Mihaiu (2014) and Mckinsey (2010).

Diagram 1: depicting components public sector performance measurement

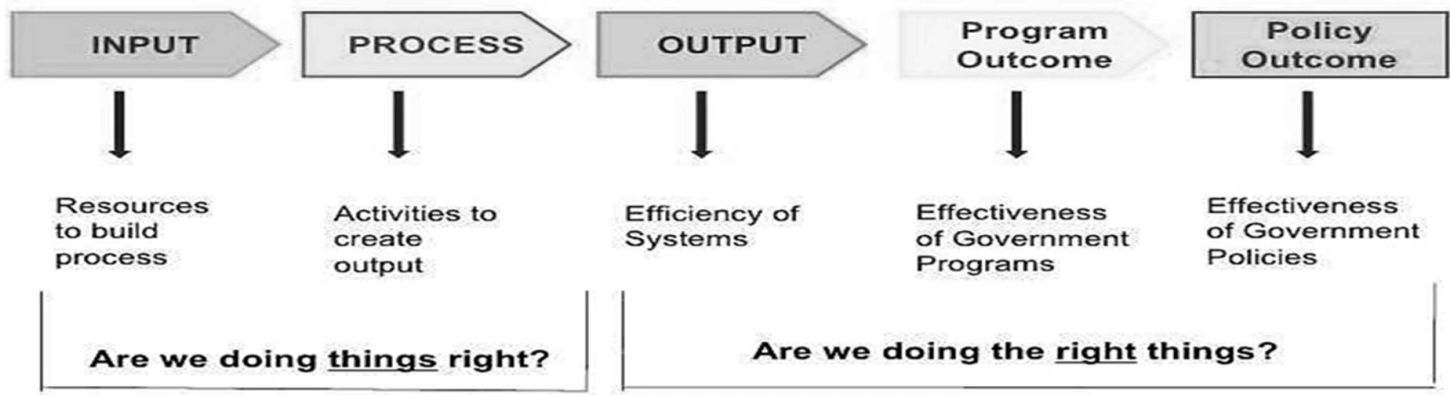

Diagram of public sector performance measurement Courtesy Mihaiu (2014)

Proposal 4: Scholars like Hans (2010), Comaniciu et al (2012), and Rohm, (2002), amongst other scholars have proposed public sector performance models that measure public sector performance by capturing issues that are of economic and social importance.

Other Proposals: These models as captured and described in the table 1 below consist of total quality management, balanced score card, bench marking and public service value models all of which have been modified to address the issues around public-sector performance. 


\section{Table1: Public Sector Performance Measuring and Evaluating Models}

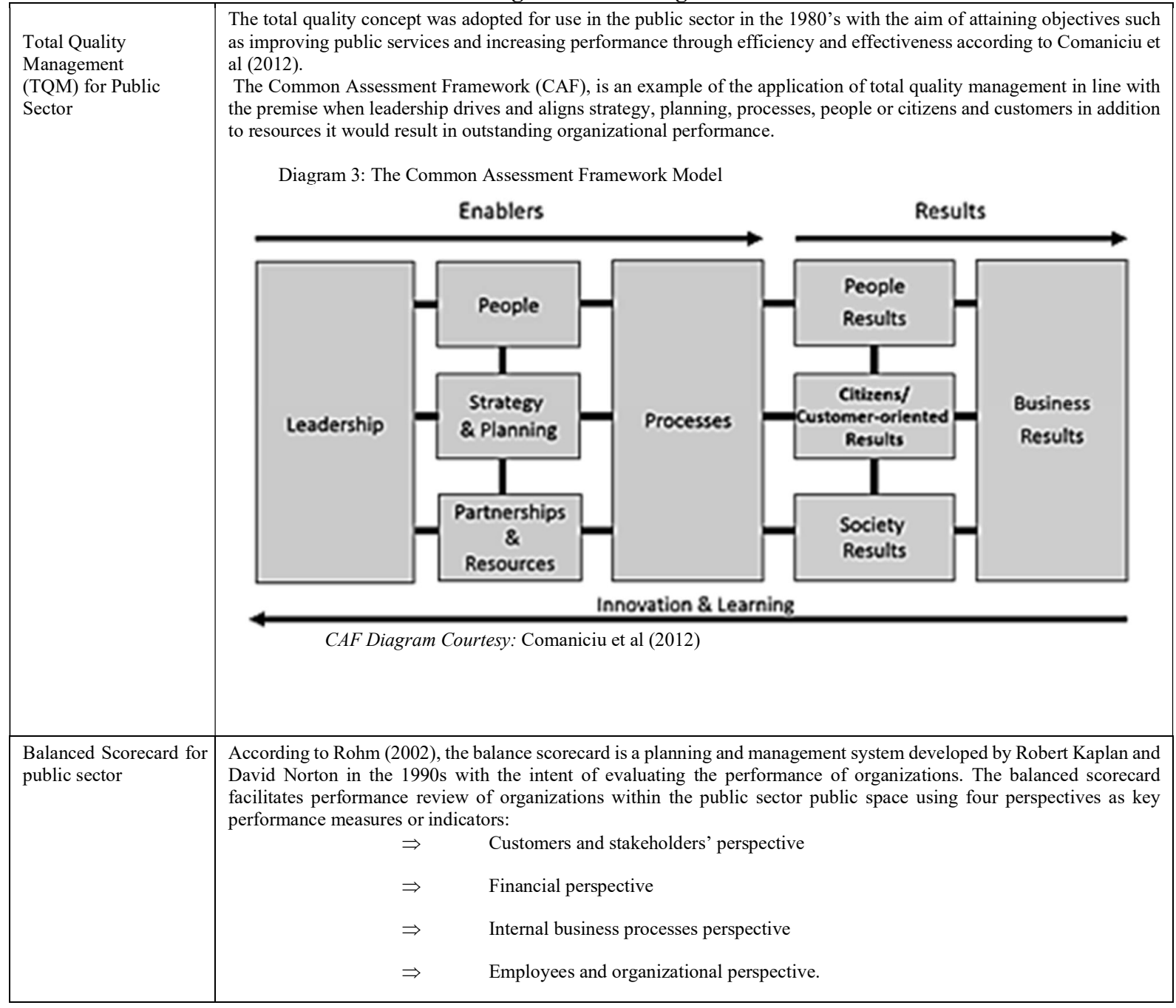


ii. The Federal Government of Nigeria should summon the political will to harmonize and implement relevant recommendations from the various committee reports. Some of these include, Service Delivery (Servicom), Restructuring and Re-positioning of the MDAs, Maximum of eight (8) years tenor for Permanent Secretaries and categories of Directors, etc.

iii. Recruitment into the public service should be based on merit rather than the present approach which is based on favouritism, ethnicity, nepotism, religious and regional bias.

iv. Civil service rules should be made flexible to allow for workers' initiatives in response to external or environmental changes.

v. Appropriate mechanism to evaluate the civil service effectiveness indexes like the ease of doing business, competiveness and utility service provision indexes as published by the world economic forum and other think tanks, should be further emphasized as means of measuring public sector performance in Nigeria.

vi. Finally the reward system in the public service should be such that provide incentives to bureaucrats who performances are outstanding as well as those who adhere to ideal bureaucratic tenets in performing their duties.

\section{References}

Adedire, S. (2014). Re-inventing Nigerian civil service for effective service delivery in the $21^{\text {st }}$ century. Fountain Journal of Management and Social Sciences, Vol 4(1), 104-119

Ake, M. \& Olowojolu, O. (2016). Nigeria civil service reforms of 1999 - 2007: An analysis of the controversies. Africology: The Journal of Pan African Studies, Vol 9 (3), 66 - 78

Al-Maktoum, M. (2013). Flashes of Thought: Lessons in Life and Leadership (inspired by a dialogue at the government summit 2013), published by Motivate Publishing/Emirates Printing Press.

Anazodo, R. et al., (2012). Civil service reforms in Nigeria: The journey so far in service delivery. American Journal of Social and Management Sciences, Vol 3 (1), 17 - 29

Boyne, G., et al., (2006). Public Service Performance, Cambridge University Press.

Comaniciu, C., \& Bunescu, L. (2012). Coordinates of Total Quality Management in Fiscal Administration, Review of general Management, volume 12, issue 2, pg.139-148.

De Smet, A., et al., (2007). The Missing Link: Connecting organizational and financial performance (working paper) accessed $15^{\text {th }}$ July 2017 from http://www.mckinsey.com

Global Competitiveness Report 2015-2016: Full Data Edition as published by the World Economic Forum (Geneva).

Graph of Competitiveness ranking and Country Indicators retrieved from http://www.tradingeconomics.com/Nigeria/indicators assessed on 30th July 2017.

Hans, D. (2010). Managing Performance in the Public Sector, $2^{\text {nd }}$ Edition, Routledge, Taylor and Francis Group, 2007, pg. $17-33$.

Handler, H., et al., (2004). The Size and Performance of Public Sector Activities In Europe, work prepared by the authors for European Commission's Competitiveness Report 2004 available online at http://papers.ssrn.com/sol3/papers.cfm?abstract_id=1861528

McKinsey, A. (2010). Making it work in government: perspectives on transforming performance in the public sector: accessed on $25^{\text {th }}$ June 2017 from www.McKinsey.com

McKinsey, A. (2011). Better for Less: Improving Public Sector Performance on a tight budget (discussion paper) accessed $15^{\text {th }}$ July 2017 from http://www.mckinsey.com)

Mihaiu, D., et al., (2014). Measuring Performance in The Public Sector: Between Necessity and Difficulty Article provided by Lucian Blaga University of Sibiu, Faculty of Economic Sciences in its journal Studies in Business and Economics. (assessed $5^{\text {th }}$ July 2017 http://eccsf.ulbsibiu.ro/RePEc/blg/journl/925mihaiu.pd) 
Morgan, M., et al., (2019). A Critque of the Bureaucratic Theory: The Nigerian Civil Service Experience. Global Journal of Social Science, Vol. 18 (1), 1-10

Obioji, J. (2019). Implementation of civil service reforms in Southeast Nigeria: Areview of service compact with all Nigerians (Servicom). Global Journal of Human Resource Management, Vol 7 (1), 1 - 15

Ogunrotifa, A. (2012) 'Weberian Bureaucracy and its Problems in Nigeria: Proposing Democratic Centralism in the Management of Public Institutions'. Asian Journal of Research in Social Sciences and Humanities, Vol. 2(10), $1-24$

Ogunrotifa, A. (2012). Federal civil service reform in Nigeria: The case of democratic centralism. Radix International Journal of Research in Social Sciences, Vol 1 (10), 1 - 45

Ojokuku R., et al., (2012). Impact of Leadership Style on Organizational Performance: A Case Study of Nigerian Banks American Journal of Business and Management Vol. 1, No. 4, 2012, 202-207

Olatunji, K. (2017). Nigeria In Need of Transformational Leaders (discussion paper) assessed July 31 $1^{\text {st }}, 2017$ from Guardian online https://guardian.ng/politics/nigeria-in-need-of-transformational-leaders/

Okonjo-Iweala, N. (2012). Reforming the Unreformable: Lessons from Nigeria (MIT Press)

Profiroiu, M., \& Profiroiu, A. (2001). Public Sector Performance Analysis Framework, in the journal "Theoretical and Applied Economics" available online at http://store.ectap.ro/articole/180.pdf, Management of Public Organizations, Bucharest, Economic Publishing House.

Rohm, H. (2002). Improve Public Sector Results with a Balanced Scorecard: nine steps to success, U.S Foundation for Performance Measurement.

Ştefănescu, A., et al (2010). Approaches of The Role of Performance into The Public-Sector Entities from Romania, TIBISCUS, Annals. Economic Science Series (XVI/2010). 